\title{
TETRAFERRIPHLOGOPITE FROM THE SIILINJÄRVI CARBONATITE COMPLEX, FINLAND
}

\author{
Kauko Puustinen
}

\begin{abstract}
Puustinen, Kauko 1973: Tetraferriphlogopite from the Siilinjärvi carbonatite complex, Finland. Bull. Geol. Soc. Finland 45, 35-42.

Chemical and physical data is given for tetraferriphlogopite from the Siilinjärvi carbonatite complex, eastern Finland. Chemical analyses show Al deficiency in the tetrahedral sites of the mineral, this being compensated for by the $\mathrm{Fe}^{3+}$ ion. The presence of ferric iron in this coordination causes the anomalous pleochroic colors, $\mathrm{X}=$ deep reddish brown and $\mathrm{Y}, \mathrm{Z}=$ pale green, with the absorption formula $\mathrm{X}>\mathrm{Y}=\mathrm{Z}$.
\end{abstract}

Kauko Puustinen, Helsinki University of Tecbnology, Dept. of Mining and Metallurgy, 02150 Otaniemi, Finland.

\section{Introduction}

The study of carbonatite complexes has revealed the discovery of a mica type with chemical and optical peculiarities. The common phlogopite has the absorption formula $\mathrm{X}<\mathrm{Y}=\mathrm{Z}$ with pleochroic colors $\mathrm{X}=$ yellow and $\mathrm{Y}=\mathrm{Z}=$ brownish red, green or yellow. In some cases phlogopite shows anomalous pleochroic colors $\mathrm{X}=$ deep reddish brown and $\mathrm{Y}=\mathrm{Z}=$ pale yellow with $\mathrm{X}>\mathrm{Y}=\mathrm{Z}$. The absorbance cannot be visually resolved in thin sections parallel to (001) since the absorbance of $\mathrm{Y}$ is almost equal to that of $\mathrm{Z}$; these are treated as $\mathrm{Y}, \mathrm{Z}$.

Biotite with the anomalous, reversed, pleochroism has also been found. The term biotite, $\mathrm{K}_{2}\left(\mathrm{Fe}^{2+}, \mathrm{Mg}\right)_{6}\left[\mathrm{Si}_{6} \mathrm{Al}_{2} \mathrm{O}_{20}\right](\mathrm{OH})_{4}$, is used in this paper to denote an iron rich mica which is arbitrarity differentiated from phlogopite,
$\mathrm{K}_{2}\left(\mathrm{Mg}, \mathrm{Fe}^{2+}\right)_{6}\left[\mathrm{Si}_{6} \mathrm{Al}_{2} \mathrm{O}_{20}\right](\mathrm{OH})_{4}$, in having $\mathrm{Mg}: \mathrm{Fe}<2: 1$. Phlogopite and biotite can, however, be treated together since the anomalous optics are due to the chemical differences in the tetrahedral sites of the mineral structure.

Pleochroism in minerals is caused by the differential absorption of polarized light in different crystallographic directions and is seen as different colors when light in the visible region is affected. The majority of silicates owe their colors to the presence of transition metals (e.g. Fe) and lanthanide ions in the structures, these absorbing light through internal $d$ or $f$ electron transitions. The occurrence of these ions in coordination sites disturbed from octahedral or tetrahedral symmetry gives rise to pleochroism (Burns, 1970).

Phlogopite and biotite with an anomalous pleochroism is named by Rimskaya-Korsakova and Sokolova (1964) tetraferriphlogopite and tetra- 
ferribiotite, respectively. This terminology is also adopted in the present paper.

The term tetraferriphlogopite, $\mathrm{K}_{2} \mathrm{Mg}_{6} \quad\left[\mathrm{Si}_{6}\right.$ $\left.\left(\mathrm{Al}, \mathrm{Fe}^{3+}\right)_{2} \mathrm{O}_{20}\right](\mathrm{OH})_{4}$, shows the presence of ferric iron in the tetrahedral sites of the mica structure. It is known that $\mathrm{Fe}^{3+}$ may completely replace $\mathrm{Al}^{3+}$ in phlogopite (Steinfink, 1962). The anomalous pleochroism also appears in synthetic ferriannite $\mathrm{KFe}^{2+}{ }_{3}\left[\mathrm{Si}_{3} \mathrm{Fe}^{3+} \mathrm{O}_{10}\right](\mathrm{OH})_{2}$ (Wones, 1963).

This paper describes the anomalous phlogopite found in the Siilinjärvi carbonatite complex. Since the complex has been described in details by Puustinen (1971), only the main features are presented here.

The complex is located some $20 \mathrm{~km}$ to the north of the city of Kuopio in eastern Finland, at lat. $63^{\circ} 08^{\prime} \mathrm{N}$ and long. $27^{\circ} 44^{\prime} \mathrm{E}$.

The roughly tabular, subvertical complex is some $16 \mathrm{~km}$ long and up to $1.5 \mathrm{~km}$ wide. The age is about $2500 \mathrm{~m}$.y. determined with the $\mathrm{K}-\mathrm{Ar}$ method from richterite (Puustinen, 1972). Ages between 1785 and 2030 m.y. from phlogopite give unsatisfactory results for the time of emplacement. The datings probably represent the ages of the Svecokarelian movements, during which the fracturing was concentrated to the south of Silinjärvi. Only restricted fracture zones cut the complex and the surrounding basement.

New age determinations (K-Ar) of two Siilinjärvi minerals were carried out by Dr. V. Kononova and Dr. E. Sveshnikova, IGEM, Moscow. The age for phlogopite from glimmerite is $1850 \pm 40$ m.y. and for richterite from amphibole glimmerite is $2280 \pm 40$ m.y. Both rock samples are taken from the Särkilampi area.

The rocks comprise (from the oldest to the youngest) glimmerite, syenite and carbonatite (sövite) and are intrusive into the surrounding granite gneiss.

Glimmerite is usually medium-grained with color varying from red-brown to black. The rock consists of phlogopite, alkali-amphibole (richterite) and apatite with carbonates (less than
$5 \%$ ), iron oxides, sulphides and zircon being present as accessories. In the northern parts of the complex a serpentine-rich variety (mica peridotite) is also found.

The carbonatite proper is a leucocratic rock, generally medium-grained. The main constituent is calcite with phlogopite, alkali-amphibole, dolomite and apatite as accessory minerals. Carbonatite with predominating dolomite (rauhaugite) or ankerite has not been found.

The emplacement of the various magmatic phases took place in the same deep-seated fracture. The carbonatitic phase was more readily intruded into the glimmeritic rocks than into a more compact syenite which mantles the other rocks from almost all sides. The grading over of the carbonatite proper into a mixed rock of carbonate-rich glimmerite is demonstrated in many places. Various rocks are thus distinguished and named on the basis of the relative abundance of the essential minerals. The different types occur completely irregularly, the thickness of the bodies varying from a few centimeters to tens of meters.

\section{Occurrence}

Among the glimmerite-carbonatite rock series of the Siilinjärvi complex the relative abundance of glimmerite (carbonate content $0-5 \%$ ), carbonate glimmerite (carbonate content 5-25\%) and carbonatite proper (carbonate content 50 $100 \%$ ) are $18.5,58.7$ and $6.0 \%$, respectively (Puustinen, 1971). These figures give the idea of the amount of phlogopite in the rocks.

The distribution of the normally pleochroic mica and the anomalously pleochroic mica is irregular, varying in different parts of the complex and also in adjacent types of glimmerite. The connection between the anomalous phlogopite and any particular rock-type or structural position could not be specified.

In the carbonatite proper the amount of phlogopite is small, the mineral occurring mainly as 
euhedral crystals, measuring in rare cases up to $10 \mathrm{~cm}$.

In thin section the mica looks fresh and shows no sign of being an alteration product of amphibole or pyroxene. As vermiculite has not been discovered, this suggests that the present erosion level of the complex has not been in a favourable weathering position to form vermiculite by the hydration of normal mica such as phlogopite by loss of alkalies and addition of water. Chlorite has been formed only in very small quantities as an alteration product of phlogopite in narrow foliated zones in glimmerite.

\section{Chemical composition}

The chemical composition of the Siilinjärvi phlogopite is presented in Table 1. Atomic ratios were calculated based upon 24 anions $(\mathrm{O}, \mathrm{OH}, \mathrm{F})$. The ions were grouped in $\mathrm{Z}$-, $\mathrm{Y}$ - and $\mathrm{X}$-type cations and in the $(\mathrm{OH}, \mathrm{F})$-group. The sum of the Z-type cations was calculated as 8.00 , representing the tetrahedrally coordinated $\mathrm{Si}, \mathrm{Al}$, and $\mathrm{Fe}^{3+}$. Ferric iron was needed in case the tetrahedral sites were not filled with $\mathrm{Si}$ and $\mathrm{Al}$. The distribution of cations in these sites is the main interest of the present study.

By composition, the first two analyses correspond to tetraferriphlogopite, showing the presence of $\mathrm{Fe}^{3+}$ in the tetrahedral sites of the mineral. The third analysis represents, chemically, a common phlogopite. Physical or optical data for this specimen are unfortunately not available.

In order to summarize the general relations of the chemical composition of the mica from carbonatite complexes, selected analyses from the following localities were surveyed: Finland (this paper),Kola Peninsula (Rimskaya-Korsakova and Sokolova, 1964; Kukharenko and others, 1965; Kononova and others, 1969), Montana (Boettcher, 1967), Siberia (Chernysheva and Gormasheva, 1966), Quebec (Gold, 1964; Hogarth and others, 1970) and South Africa (Gevers, 1948). The single analyses are not reproduced
TABLE 1

Chemical composition (Wt. \%) and atomic ratios based on 24 anions of phlogopite, Siilinjärvi

\begin{tabular}{|c|c|c|c|}
\hline & 1. & 2. & 3. \\
\hline $\mathrm{SiO}_{2} \ldots \ldots \ldots \ldots$ & 41.18 & 40.69 & 43.18 \\
\hline $\mathrm{TiO}_{2} \quad \ldots \ldots \ldots \ldots$ & 0.04 & 0.04 & 0.32 \\
\hline $\mathrm{Al}_{2} \mathrm{O}_{3} \quad \ldots \ldots \ldots \ldots$ & 10.57 & 12.19 & 10.22 \\
\hline $\mathrm{Fe}_{2} \mathrm{O}_{3} \quad \ldots \ldots \ldots \ldots$ & 4.55 & 2.73 & 3.15 \\
\hline $\mathrm{FeO} \ldots \ldots \ldots \ldots \ldots$ & 3.80 & 4.72 & 5.24 \\
\hline $\mathrm{MnO} \ldots \ldots \ldots \ldots$ & 0.01 & 0.01 & 0.05 \\
\hline $\mathrm{MgO} \ldots \ldots \ldots \ldots$ & 24.86 & 23.90 & 23.88 \\
\hline $\mathrm{CaO} \ldots \ldots \ldots \ldots$ & 0.21 & 0.07 & 0.70 \\
\hline $\mathrm{Na}_{2} \mathrm{O} \ldots \ldots \ldots \ldots$ & 0.56 & 0.64 & 0.18 \\
\hline $\mathrm{K}_{2} \mathrm{O} \ldots \ldots \ldots \ldots$ & 9.96 & 9.91 & 10.03 \\
\hline $\mathrm{P}_{2} \mathrm{O}_{5} \quad \ldots \ldots \ldots \ldots \ldots$ & 一 & - & 0.12 \\
\hline$F \ldots \ldots \ldots \ldots \ldots$ & 0.70 & 0.39 & 0.75 \\
\hline $\mathrm{H}_{2} \mathrm{O}^{+} \ldots \ldots \ldots \ldots \ldots$ & 2.98 & 3.81 & 2.22 \\
\hline $\mathrm{H}_{2} \mathrm{O}-\ldots \ldots \cdots \cdots \cdots$ & 0.34 & 0.29 & 0.38 \\
\hline & 99.76 & 99.39 & $\overline{100.42}$ \\
\hline$-\mathrm{O} \equiv \mathrm{F}$ & 0.29 & 0.16 & 0.32 \\
\hline Total & 99.47 & 99.73 & $\overline{100.10}$ \\
\hline Si & 6.00 & 5.88 & 6.30 \\
\hline $\mathrm{Z}\left\{\mathrm{Al}\left[{ }^{4}\right]\right.$ & 1.82 & 2.08 & 1.70 \\
\hline $\left.\mathrm{Fe}^{3+}{ }^{4}\right] \quad \ldots \ldots \ldots$ & 0.18 & 0.04 & 0.00 \\
\hline $\mathrm{Al}\left[{ }^{6}\right] \ldots \ldots \ldots$ & 0.00 & 0.00 & 0.06 \\
\hline $\mathrm{Ti}^{2} \ldots \ldots \ldots \ldots$ & 0.00 & 0.00 & 0.04 \\
\hline$Y\left\{\mathrm{Fe}^{3+[6]} \quad \ldots \ldots \ldots\right.$ & 0.32 & 0.26 & 0.35 \\
\hline $\mathrm{Fc}^{2+} \ldots \ldots \ldots \ldots$ & 0.46 & 0.57 & 0.64 \\
\hline $\mathrm{Mn} \ldots \ldots \ldots$ & 0.00 & 0.00 & 0.01 \\
\hline $\mathrm{Mg} \ldots \ldots \ldots \ldots$ & 5.40 & 5.15 & 5.20 \\
\hline $\mathrm{Ca} \ldots \ldots \ldots \ldots$ & 0.03 & 0.01 & 0.11 \\
\hline $\mathrm{X}\{\mathrm{Na} \ldots \ldots \ldots \ldots$ & 0.16 & 0.18 & 0.05 \\
\hline$K \ldots \ldots$ & 1.85 & 1.83 & 1.87 \\
\hline $\mathrm{OH} \ldots$ & 2.90 & 3.67 & 2.16 \\
\hline$F \ldots \ldots \ldots \ldots$ & 0.32 & 0.18 & 0.35 \\
\hline$\Sigma \mathrm{Z} \ldots$ & 8.00 & 8.00 & 8.00 \\
\hline$\Sigma Y \ldots \ldots \ldots$ & 6.18 & 5.98 & 6.30 \\
\hline$\Sigma x \ldots \ldots \ldots$ & 2.04 & 2.02 & 2.03 \\
\hline$\left.\Sigma \mathrm{OH}, \mathrm{F}^{1}\right) \ldots$ & 3.22 & 3.85 & 2.51 \\
\hline $100 \mathrm{Mg} \ldots \mathrm{.}$. & 84.86 & 85.56 & 83.97 \\
\hline $\mathrm{Mg}+\mathrm{Fe}+\mathrm{Mn} \ldots$ & & & \\
\hline
\end{tabular}

1. Tetraferriphlogopite from glimmerite, Lake Särkilampi. Analysis by Tapio Koljonen. (86/KP - 67).

2. Tetraferriphlogopite from sövite, Lake Särkilampi. Analysis by Tapio Koljonen. (204-2/KP-69).

3. Phlogopite from glimmerite, south of Lake Särkilampi. (Puustinen, 1971).

1) Deficiency in the $(\mathrm{OH}, \mathrm{F})$ group is compensated with $\mathrm{O}$.

here since the data is presented in Fig. 1 as a $\mathrm{Si}-\mathrm{Al}-\mathrm{Fe}^{3}+$ diagram and in Tables 2 and 3 as a correlation matrix between the elements and an arithmetic mean and standard deviation of the elements. 


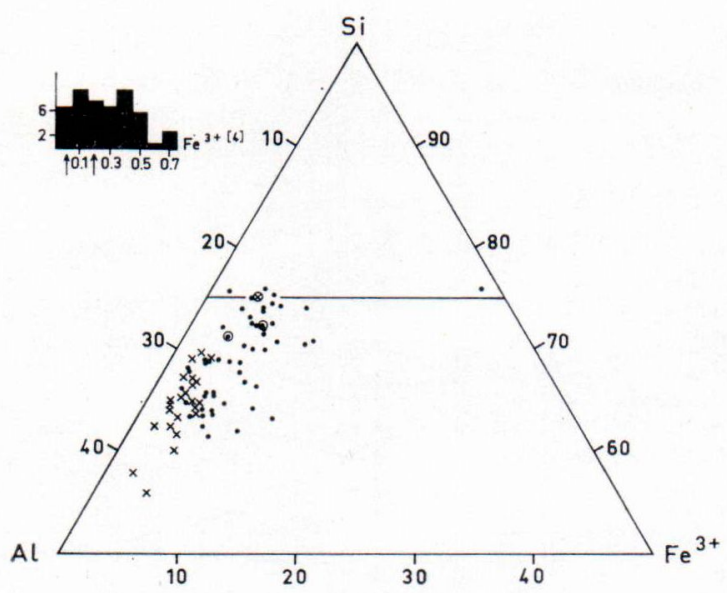

Fig. 1. $\mathrm{Si}-\mathrm{Al}_{\text {tot. }}-\mathrm{Fe}_{\mathrm{tot}}^{3^{+}}$(atomic numbers) diagram of tetraferriphlogopite $(\cdot)$ and common phlogopite $(x)$. The Siilinjärvi phlogopites are ringed. The figures also shows the frequency distribution of the tetrahedrally coordinated ferric iron. The Siilinjärvi phlogopites are marked with an arrow.

Fig. 1 shows that the common phlogopite has a variation almost parallel to the $\mathrm{Si}-\mathrm{Al}$ line, with an average of $3 \%$ relative $\mathrm{Fe}^{3+}$ in the diagram. Tetraferriphlogopite has a larger spread than the common phlogopite. The relative $\mathrm{Fe}^{3+}$ content, according to the diagram, is an average of $5 \%$. Tetraferriphlogopite superimposes on the common phlogopite, suggesting that there is a chemical series between these mineral types.
The common phlogopite from Siilinjärvi (Table 1, No. 3) is anomalously situated in the $\mathrm{Si}-\mathrm{Al}-\mathrm{Fe}^{3}+$ diagram, possibly due to an analytical error. The exceptional mica from the Sebljavrskij massif (Rimskaya-Korsakova and Sokolova, 1964) suggests that there is a series between the ordinary distributed micas and the theoretical tetraferriphlogopite $\mathrm{K}_{2} \mathrm{Mg}_{6}\left[\mathrm{Si}_{6} \mathrm{Fe}_{2}{ }^{3+}\right.$ $\left.\mathrm{O}_{20}\right](\mathrm{OH})_{4}$.

Fig. 1 also shows the frequency histogram of the $\mathrm{Fe}^{3}+\left[{ }^{4}\right]$ of the selected analyses. The position of the Siilinjärvi tetraferriphlogopites is indicated with an arrow.

The study of the matrix of correlation coefficients between the elements of tetraferriphlogopite, expressed in atomic numbers (Tables 2 and 3), shows that Si correlates with $\mathrm{Al}\left[{ }^{4}\right]$ and $\mathrm{Fe}^{3}+\left[{ }^{4}\right], \mathrm{Al}\left[{ }^{4}\right]$ with $\mathrm{Fe}^{3}+\left[{ }^{4}\right]$, Ti and $\mathrm{Fe}^{3+}\left[{ }^{6}\right]$, Ti with $\mathrm{Fe}^{2+}$, and $\mathrm{Mg}$ with $\left.\mathrm{Si}, \mathrm{Al}\left[{ }^{4}\right], \mathrm{Ti}, \mathrm{Fe}^{3+}{ }^{6}\right]$ and $\mathrm{Fe}^{2+}$. In the common phlogopite $\mathrm{Si}$ and $\mathrm{Al}\left[{ }^{4}\right]$ correlate with $\mathrm{K}$ and $\mathrm{OH}, \mathrm{Mg}$ with $\mathrm{Ti}$ and $\mathrm{Fe}^{2+}$, and $\mathrm{Na}$ and $\mathrm{OH}$ with $\mathrm{F}$. The estimation was carried out in cases when the correlation coefficient is more than \pm 0.50 . It must be pointed out that the correlation between $\mathrm{Si}$ and $\mathrm{Al}\left[{ }^{4}\right]$ in the common phlogopite is trivial because of the eight Z-type cations. The correlation between $\left.\mathrm{Fe}^{3+}{ }^{4}\right]$ and the other elements show that the amount of this ion

TABLE 2.

Matrix of correlation coefficients between the elements (atomic numbers) for 54 tetraferriphlogopites.

$\overline{\mathrm{X}}=$ arithmetic mean and $\mathrm{s}=$ standard deviation

\begin{tabular}{|c|c|c|c|c|c|c|c|c|c|c|c|c|c|c|}
\hline & $\mathrm{Si}$ & $\mathrm{Al}\left[{ }^{4}\right]$ & $e^{3+}\left[{ }^{4}\right]$ & $\operatorname{Al}\left[{ }^{6}\right]$ & $\mathrm{Ti}$ & $\mathrm{Fe}^{3+}\left[{ }^{6}\right]$ & $\mathrm{Fe}^{2+}$ & $\mathrm{Mn}$ & $\mathrm{Mg}$ & $\mathrm{Ca}$ & $\mathrm{Na}$ & $\mathrm{K}$ & $\mathrm{OH}$ & F \\
\hline 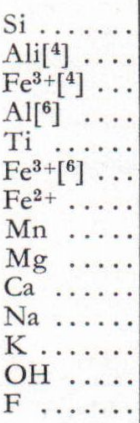 & 1.00 & $\begin{array}{r}-0.79 \\
1.00\end{array}$ & $\begin{array}{r}0.50 \\
-0.88 \\
1.00\end{array}$ & - & $\begin{array}{r}-0.43 \\
0.50 \\
-0.39 \\
1.00\end{array}$ & $\begin{array}{r}-0.40 \\
0.58 \\
-0.42 \\
\\
0.41 \\
1.00\end{array}$ & $\begin{array}{r}-0.03 \\
0.16 \\
-0.16 \\
0.65 \\
0.34 \\
1.00\end{array}$ & $\begin{array}{r}0.08 \\
-0.07 \\
0.09 \\
\\
0.10 \\
0.07 \\
0.29 \\
1.00\end{array}$ & $\begin{array}{r}0.50 \\
-0.53 \\
0.38 \\
\\
-0.70 \\
-0.63 \\
-0.77 \\
-0.14 \\
1.00\end{array}$ & $\begin{array}{r}-0.48 \\
0.28 \\
-0.13 \\
-0.06 \\
0.13 \\
-0.12 \\
0.03 \\
-0.25 \\
1.00\end{array}$ & $\begin{array}{r}-0.33 \\
0.26 \\
-0.09 \\
0.23 \\
0.23 \\
0.01 \\
-0.08 \\
-0.18 \\
-0.02 \\
1.00\end{array}$ & $\begin{array}{r}0.47 \\
-0.34 \\
0.15 \\
-0.24 \\
-0.39 \\
-0.15 \\
0.39 \\
0.36 \\
-0.12 \\
-0.20 \\
1.00\end{array}$ & $\begin{array}{r}-0.49 \\
0.14 \\
-0.07 \\
-0.20 \\
-0.23 \\
-0.34 \\
-0.37 \\
-0.07 \\
0.39 \\
-0.08 \\
-0.34 \\
1.00\end{array}$ & $\begin{array}{r}0.45 \\
-0.40 \\
0.24 \\
-0.29 \\
-0.20 \\
-0.10 \\
0.18 \\
0.29 \\
-0.22 \\
0.10 \\
0.40 \\
-0.36 \\
1.00\end{array}$ \\
\hline $\begin{array}{l}\bar{X} \ldots \\
\text { s } \ldots\end{array}$ & $\begin{array}{l}5.60 \\
0.23\end{array}$ & $\begin{array}{l}2.03 \\
0.47\end{array}$ & $\begin{array}{l}0.30 \\
0.28\end{array}$ & $\begin{array}{r}0.00 \\
-\end{array}$ & $\begin{array}{l}0.10 \\
0.1\end{array}$ & $\begin{array}{l}0.18 \\
0.19\end{array}$ & $\begin{array}{l}0.58 \\
0.47\end{array}$ & $\begin{array}{l}0.02 \\
0.03\end{array}$ & $\begin{array}{l}4.81 \\
0.70\end{array}$ & $\begin{array}{l}0.10 \\
0.11\end{array}$ & $\begin{array}{l}0.20 \\
0.12\end{array}$ & $\begin{array}{l}1.72 \\
0.16\end{array}$ & $\begin{array}{l}4.39 \\
1.02\end{array}$ & $\begin{array}{l}0.30 \\
0.27\end{array}$ \\
\hline
\end{tabular}


TABLE 3 .

Matrix of correlation coefficients between the elements (atomic numbers) for 25 common phlogopites. $\overline{\mathrm{X}}=$ arithmetic mean and $\mathrm{s}=$ standard deviation

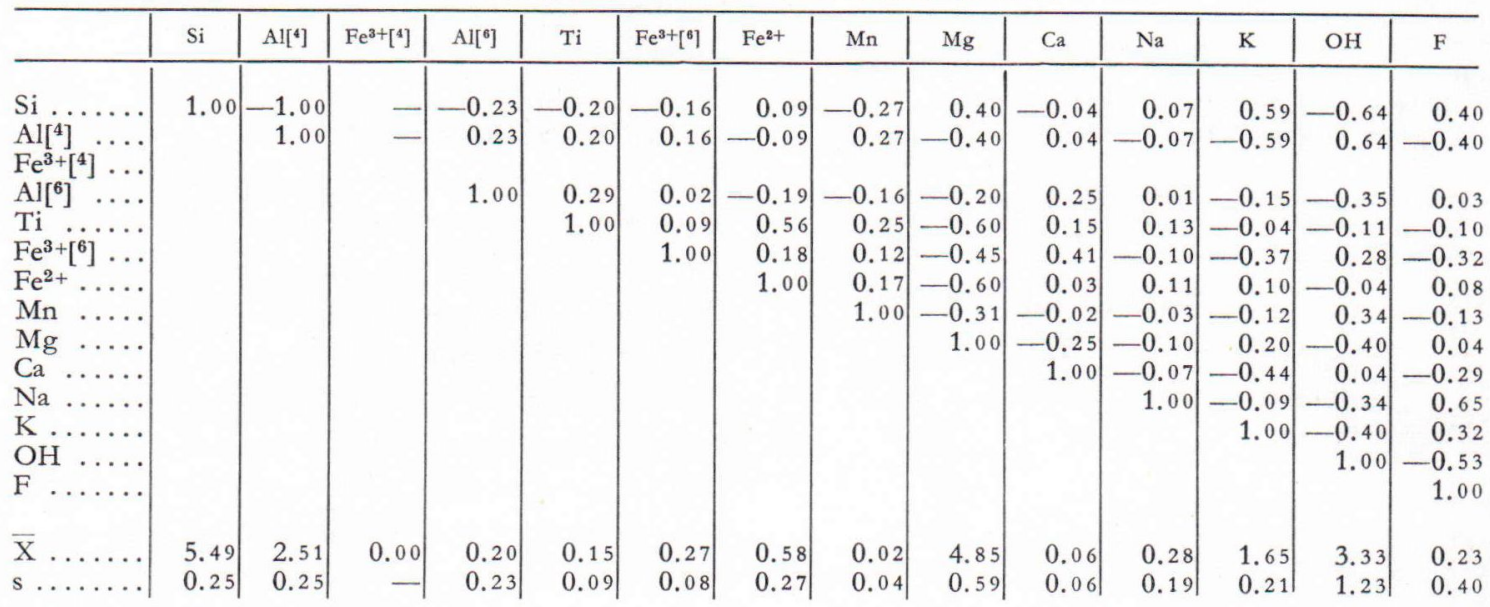

is mainly dependent on the relative amounts of $\mathrm{Si}$ and $\mathrm{Al}$ in the mineral composition.

Tables 2 and 3 also show that tetraferriphlogopite has a higher $\mathrm{Si}, \mathrm{Fe}^{3+}, \mathrm{OH}$ and $\mathrm{F}$ content and on the other hand a smaller $\mathrm{Al}$, Ti, $\mathrm{Mg}$ and $\mathrm{Na}$ content than the common phlogopite. Comparing the standard deviations between both types of mica, large differences exist in $\mathrm{Al}, \mathrm{Fe}^{3+}$, and $\mathrm{OH}$. In some analyses the $\mathrm{H}_{2} \mathrm{O}+$ (Wt. \%) is expressed anly as $\mathrm{H}_{2} \mathrm{O}$, this fact explaining the relatively large variation of $\mathrm{OH}$.

\section{Physical properties}

The unit cell parameters, the $1 \mathrm{M}$ polytype assumed, of the chemically analyzed Siilinjärvi tetraferriphlogopites (Table 4, Nos. 1 and 2) were calculated from silicon calibrated X-ray powder diagrams. The accuracy obtained corresponds to probable errors of $0.01 \AA$ and $0^{\circ} 10^{\prime}$. The results are in agreement with the values usually given for phlogopites.

Absorption properties of the Siilinjärvi phlogopites were examined with a LEITZ microscope photometer with a KNOTT light measuring device. The direct light of each thin section was
TABLE 4.

Physical properties and unit cell dimensions of tetraferriphlogopite, Siilinjärvi

\begin{tabular}{|c|c|c|}
\hline & 1. & 2. \\
\hline$\alpha \ldots \ldots \ldots \ldots$ & 1.561 & 1.559 \\
\hline$\beta, \gamma \ldots \ldots \ldots \ldots$ & 1.600 & 1.607 \\
\hline$\gamma-\alpha \ldots \ldots \ldots \ldots$ & 0.039 & 0.048 \\
\hline $\mathrm{X} \ldots \ldots \ldots \ldots$ & 1. br. & d. r. br. \\
\hline $\begin{array}{l}Y, Z \ldots \ldots \ldots \\
\mathrm{D}(\mathrm{g} / \mathrm{cc}) \\
\ldots\end{array}$ & $\begin{array}{l}\text { 1. gr. } \\
2.839\end{array}$ & $\begin{array}{l}\text { 1. gr. } \\
2.846\end{array}$ \\
\hline$a_{0}(\AA) \quad \ldots \ldots \ldots \ldots$ & 5.33 & 5.34 \\
\hline$b_{0} \ldots \ldots \ldots \ldots$ & 9.26 & 9.25 \\
\hline$c_{o} \ldots \ldots \ldots \ldots$ & 10.29 & 10.29 \\
\hline$\beta \ldots \ldots \ldots \ldots$ & $99^{\circ} 58^{\prime}$ & $99^{\circ} 56^{\prime}$ \\
\hline $\mathrm{a}_{0} \sin \beta \quad(\AA) \quad \ldots \ldots \ldots$ & 5.25 & 5.26 \\
\hline $\mathrm{V}\left(\AA^{3}\right) \ldots \ldots \ldots$ & 500.3 & 500.3 \\
\hline
\end{tabular}

1. = light, d. = dark, br. = brown, gr. = green and r. = reddish

1. Tetraferriphlogopite from glimmerite, Lake Särkilampi. (86/KP-67).

2. Tetraferriphlogopite from sövite, Lake Särkilampi. (204-2/KP-69).

adjusted to $100 \%$ and the readings were measured using a galvanometer with an accuracy of $0.1 \%$. The absorbance was measured from the optic directions $\mathrm{X}$ and $(\mathrm{Y}, \mathrm{Z})$, respectively, of the same crystal. Polarized white light was used to avoid the specific absorbance of different wave lenghts and to allow the mica to be studied using optical microscopy. The results are pre- 
TABLE 5.

Absorbance ratios between optical $\mathrm{X}$ and $(\mathrm{Y}, \mathrm{Z})$ directions, pleochroic colors and optic angles of 21 tetraferriphlogopites and 11 common phlogopites from Siilinjärvi. $\mathrm{GT}=$ glimmerite, $\mathrm{FGT}=$ foliated glimmerite, $\mathrm{CGT}=$ carbonate glimmerite, SCT $=$ silicocarbonatite and MPT $=$ mica peridotite. v. = very, d. = dark, $1 .=$ light, r. = reddish, br. = brown and $\mathrm{gr} .=$ green

\begin{tabular}{|c|c|c|c|c|c|}
\hline \multirow{2}{*}{$\begin{array}{l}\text { Rock } \\
\text { type }\end{array}$} & \multirow{2}{*}{$\begin{array}{l}\text { Abs. } \\
\text { ratio }\end{array}$} & \multicolumn{2}{|c|}{ Pleochroism } & \multirow{2}{*}{$2 \mathrm{~V}^{\circ}$} & \multirow{2}{*}{$\begin{array}{l}\text { Ref. } \\
\text { No. }\end{array}$} \\
\hline & & $\mathrm{x}$ & $\mathrm{Y}, \mathrm{Z}$ & & \\
\hline SCT & 0.15 & d. r. br. & v. 1. gr. & 5 & \\
\hline MPT. & 0.16 & ») & $"$ & $0-5$ & 82 \\
\hline GT .. & 0.17 & ») & $»$ & $5-10$ & 94 \\
\hline CGT . & 0.22 & $»$ & $»$ & 5 & 7 \\
\hline GT .. & 0.22 & $»$ & $»$ & $0-5$ & 79 \\
\hline SCT . & 0.31 & $»$ & $\gg$ & 5 & 73 \\
\hline CGT. & 0.35 & $»$ & $»$ & 5 & 76 \\
\hline GT .. & 0.37 & $"$ & 1. gr. & 0 & 771 \\
\hline GT .. & 0.39 & $"$ & ) & 10 & 78 \\
\hline GT .. & 0.42 & $»$ & $»$ & $5-10$ & 735 \\
\hline GT .. & 0.52 & br. & $»$ & $0-5$ & 800 \\
\hline GT .. & 0.55 & $"$ & $»$ & 5 & 74 \\
\hline MPT . & 0.55 & $"$ & v. 1. gr. & 0 & 842 \\
\hline MPT . & 0.55 & $"$ & 》) & 0 & 838 \\
\hline MPT. & 0.61 & ” & 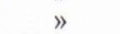 & 0 & 79 \\
\hline GT $\ldots$ & 0.62 & 1. br. & 1. br. & $0-5$ & 795 \\
\hline GT .. & 0.65 & $"$ & $»$ & 5 & 1093 \\
\hline SCT & 0.76 & $"$ & $"$ & 0 & 777 \\
\hline CG'T. & 0.80 & $"$ & $"$ & 5 & 739 \\
\hline G'T .. & 0.88 & ” & " & 5 & 760 \\
\hline CGT . & 0.95 & $"$ & $"$ & $0-5$ & 74 \\
\hline CGT . & 1.11 & $»$ & $»$ & $5-10$ & 743 \\
\hline GT .. & 1.12 & $"$ & $"$ & 0 & 1806 \\
\hline GT & 1.16 & 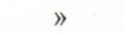 & gr. & $0-5$ & 762 \\
\hline CGT . & 1.24 & $"$ & $"$ & 15 & 780 \\
\hline FGT. & 1.58 & $»$ & d. gr. & $0-5$ & 1086 \\
\hline FGT. & 1.92 & $"$ & 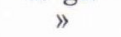 & 10 & 811 \\
\hline FGT. & 2.74 & $»$ & $"$ & 10 & 740 \\
\hline CGT. & 3.68 & v. 1. br. & $»$ & 10 & 779 \\
\hline FGT. & 4.82 & $"$ & $"$ & 15 & 774 \\
\hline FGT. & 5.05 & $»$ & $"$ & 15 & 822 \\
\hline FGT & 6.15 & " & $"$ & $15-20$ & 807 \\
\hline
\end{tabular}

sented in Table 5 as ratios between the absorbance of the optic directions. In this manner the error due to the thickness of the thin section is avoided.

It is observed that the phlogopites with an anomalous pleochroism have a ratio less than 1.00 , in other words, the transmitted light is absorbed more in the optic $\mathrm{X}$ direction than in the $(Y, Z)$ directions. In some cases the absorbance is almost equal in both optic directions. It is also found that the mica from foliated glimmerite is on the common phlogopite side, this suggesting that under shearing the abnormal phlogopite changes its optical properties and also chemical composition and results in a green colored phlogopite with a normal absorption sheme.

It can be seen that the optic angle of the abnormal phlogopite $\left(2 \mathrm{~V}=0-5^{\circ}\right)$, estimated from conoscopic observations, is smaller than that of the normal phlogopite $\left(2 \mathrm{~V}=5-20^{\circ}\right)$. There is also a positive correlation between the absorbance ratio and the optic angle in all investigated phlogopites.

It is suggested that the micas with the abnormal pleochroism (absorbance ratio less than 1.00) represent micas which have ferric iron in the tetrahedral sites of the mineral, in other words they are tetraferriphlogopites.

Interpretation of absorption spectra by ligand or crystal field theory have explained the cause of the abnormal optical properties of tetraferriphlogopite (Faye and Hogarth, 1969). The relatively intense red-brown color which appears when polarized light vibrates perpendicular to (001) is largely due to the strong absorption of blue-green wavelengths together with the more intense background absorption of the shorter wavelengths. The transmission of red, orange and yellow gives rise to the red-brown color. In the phlogopite structure each $\mathrm{Fe}$-tetrahedron is linked to an apex of an octahedron by an unique $\mathrm{Fe}^{3+}-0$ (unbridged) bond that is perpendicular to (001). The absorbance in this direction is caused by a charge transfer $\mathrm{Fe}^{3+}\left[{ }^{4}\right]$ $\rightarrow 0^{2-}$ and the $d-d$ transitions of $\mathrm{Fe}^{3}+\left[{ }^{4}\right]$ which have their maximum intensily parallel to the optic direction $\mathrm{X}$ and also impose relatively sharp absorption spectra peaks in the ultraviolet region.

In common phlogopite, where no transition metals exist in the tetrahedral sites, the pleochroism can be directly related to the electronic interaction of the $\mathrm{Fe}^{2+}$ and other ions in the octahedral layer parallel to the cleavage plane (Faye, 1968).

Determinations of the refractive indices were carried out in oil immersion mounts, the ac- 
curacy being \pm 0.003 . Refractive indices of several other phlogopites from Siilinjärvi showed a relatively small range between 1.580 and 1.620 .

The density of the phlogopites was measured with a pycnometer. The results show almost equal values and are in agreement with the chemical composition.

\section{Discussion}

Boettcher (1967) states that the occurrence of tetraferriphlogopite appears to be almost entirely restricted to carbonatites, kimberlites and ultramafic rocks, however, some examples have also been reported for iron formations (RimskayaKorsakova and Sokolova, 1964), pegmatites (Foster, 1960) and trachyte lavas (Anwar, 1956). The relatively common occurrence of this mineral type in carbonatite complexes has also proved in the present study.

In the Kovdor massif, Kola Peninsula, tetraferriphlogopite is constantly found as an accessory mineral in the late carbonatites and also developed as fringes around phlogopite (Kononova and others, 1969); the formation of the mineral was apparently accompanied by a certain increase in the agpaiticity of the medium. In general, the mica was formed by metasomatic processes from olivinites and from the surrounding alkaline rocks; this opposite opinion of the primary origin of phlogopite is not verified in Siilinjärvi. In the Turja Peninsula Kranck (1928) has observed that the anomalous phlogopite is an alteration product of biotite in carbonatite dikes, where it especially seems to occur in connection with melanite and calcite.

In the Rainy Creek ultramafic complex, Montana, Boettcher (1967) suggests that the unusual phlogopite, which occurs in the xenoliths of the glimmerite core, results when Al-deficient ferromagnesian nodules are brought into contact with a biotite-saturated melt in a milieu of high $\mathrm{P}_{2} \mathrm{O}$ and $\mathrm{fo}_{2}$. The phlogopite with normal cores and reversed borders may represent the partial adjustment of earlier mica to this environment.

Phlogopite with normal and anomalous pleochroic zoned structures, as described by Boettcher (1967) applied to the Montana glimmerite and by Larsson (1943) of the Kalix kimberlite dikes in Sweden, has not been observed in Siilinjärvi.

It has been proposed that the anomalous optics may be the result of Mn contents similar to manganophyllite which has the same type of pleochroism as tetraferriphlogopite. This, however, is contrary to the chemical analyses of tetraferriphlogopite which shows only minor contents of $\mathrm{Mn}$ (compare also Table 1).

Chemical analyses of tetraferriphlogopite normally show high $\mathrm{Fe}_{2} \mathrm{O}_{3}$ contents and the ferric iron predominates over the ferrous form. The deficit of $\mathrm{Al}$ in the mineral compensated for by $\mathrm{Fe}^{3+}$ in the tetrahedral sites. The presence of this ion is observed as a change in the absorption formula and the pleochroic colors. Tetraferriphlogopite has further a higher content of silica, water and fluorine than the common phlogopite. Foster (1960) suggests that the low $\mathrm{Al}_{2} \mathrm{O}_{3}$ content, rather than low $\mathrm{SiO}_{2}$ content, is the reason for the insufficiency of $\mathrm{Al}$ in formulas containing little or no octahedral Al. This is also in agreement with the present observations.

In Siilinjärvi the emplacement of magmatic phases took place in a narrow deep-seated intrusive channel, the conditions, therefore, represent an almost closed system.

Phlogopite in glimmerite can be זegarded as a primary crystallization. The emplacement of carbonatite magma have converted the original common phlogopite to tetraferriphlogopite in some restricted areas. This is suggested because the anomalous mica occurs especially where the carbonate content of the rock is locally high. The presence of optically transitional types between tetraferriphlogopite and common phlogopite suggests the large variation of the chemical and physical milieu during the crystallization. The absence of zonal structures, however, shows 
that the equilibrium has been attained in glimmerite and also in the mica that has been affected by the carbonatite magma.

Acknowledgements - The manuscript was read by Dr. Atso Vorma, Geological Survey of Finland. Prof. Oke Vaasjoki, University of Helsinki, placed the absorbance measuring device at the author's disposal. The chemical analyses were carried out by Mr. Tapio Koljonen, Lic. Phil. and the unit cell calculations by Mr. Pentti Rehtijärvi, M. A., both of the University of Helsinki. Mr. Hannu Autio, M. Sc., Helsinki University of Technology, assisted the author in doing the computer calculations of the chemical analyses. Mr. John Nelson, M. Met., Helsinki University of Technology, checked the language of the manuscript.

\section{REFERENCES}

Anwar, Yehia (1956) A xenolith with abnormal biotite in the lava of Ischia. Bull. volcanologique, Ser. II, Tome 18, pp. 139-149.

Boetrcher, A. L. (1967) The Rainy Creek alkalineultramafic igneous complex near Libby, Montana. I. Ultramafic rocks and fenite. Journ. Geology 75, pp. $526-553$.

Burns, Roger G. (1970) Mineralogical applications of crystal field theory. Cambridge University Press, London.

Chernysheva, E. A. and Gormasheva, G. S. (1966) Composition and properties of micas from carbonatites (In Russian). Akad. Nauk. SSSR, Sib. Otd. Inst. Geokhim., pp. 48-68.

FAYE, G. H. (1968) The optical absorption spectra of iron in six-coordinate sites in chlorite, biotite, phlogopite and vivianite. Some aspects of pleochroism in the sheet silicates. Can. Mineralogist 9, pp. 403-425.

FAYE, G. H. and Hogarth, D. D. (1969) On the origin of »reverse pleochroism» of a phlogopite. Can Mineralogist 10 , pp. $25-34$.

Foster, Margaret (1960) Interpretation of the composition of trioctahedral micas. U. S. Geol. Surv. Prof. Paper 354-B.

Gevers, T. W. (1948) Vermiculite at Loolekop, Palabora, North Transvaal. Trans. Geol. Soc. South Africa 51, pp. $133-178$.

Gold, D. P. (1964) The minerals of the Oka carbonatite and alkaline complex, Oka, Quebec. Min. Soc. India, I. M. A. volume, pp. 108-125 [1966].

Hogarth, D. D., Brown, F. F. and Pritchard, A. M. (1970) Biabsorption, Mössbauer spectra, and chemical investigation of five phlogopite samples from Quebec. Can. Mineralogist 10 , pp. $710-722$.
Kononova, V. A., Borisevich, I. V. and Lomey ko, Ye. I. (1969) Micas as indicator minerals of metasomatic processes in the massif of ultrabasic and alkaline rocks. Internat. Geol. Rev. 11, pp. 1182-1199.

Kranck, E. H. (1928) On turjaite and the ijolite stem of Turja. Fennia 51, No. 5.

Kukharenko, A. A., Orlova, M. P., Bulakh, A. G., Bagdasarov, E. A., Rimskaya-Korsakova, O. M. Nevedov, E. I., Il'inskij, G. A., Sergejev, A. S. and Авакumova, N. B. (1965) Caledonian complex of ultrabasic, alkalic rocks and carbonatites of the Kola Peninsula and Northern Karelia (In Russian). Izdatel'stvo NEDRA, Moscow.

LARsson, WALter (1943) Zur Kenntnis der alkalinen ultrabasischen Ganggesteine des Kalix-Gebiets, NordSchweden. Sveriges Geol. Unders., Ser. C, No. 456.

Puustinen, Kauko (1971) Geology of the Siilinjärvi carbonatite complex, Eastern Finland. Bull. Comm. Geol. Finlande 249.

- (1972) Richterite and actinolite from the Siilinjärvi carbonatite complex, Finland. Bull. Geol. Soc. Finland 44 , pp. $83-86$.

Rimskaya-Korsakova, O. M. and Sokolova, E. P. (1964) On ferro-magnesian mica with a reverse scheme of absorption (In Russian). Zap. vsesojuz. min. obštš. 93, pp. $411-423$.

Steinfink, Hugo (1962) Crystal structure of a trioctahedral mica: phlogopite. Am. Mineralogist 47, pp. $886-896$.

Wones, David R. (1963) Phase equilibria of "ferriannite», $\mathrm{KFe}_{3}{ }^{2+} \mathrm{Fe}^{3+} \mathrm{Si}_{3} \mathrm{O}_{10}(\mathrm{OH})_{2}$. Am. Journ. Sci. 261, pp. $581-596$.

Manuscript received, May 19, 1972. 